\title{
Stress tolerance of Antarctic macroalgae in the early life stages
}

Nelso P. Navarro ${ }^{1,2^{*}}$, Pirjo Huovinen ${ }^{1,3}$ and Iván Gómez ${ }^{1,3}$

\begin{abstract}
Background: Early life stages of macroalgae, especially from polar species, can be highly vulnerable to physical stressors, leading to important consequences for the fate of the whole population in scenarios of changing environmental variability. In the present study, tolerance to UV and temperature stress, as measured by rapid adjustment of photochemistry, $F_{v} / F_{m}$, and photosynthetic characteristics based on P-E curves (ETR max, $a$ and $\left.E_{k}\right)$, was assessed in the early life stages of six Antarctic macroalgal species from eulittoral (Pyropia endiviifolia, Iridaea cordata, Adenocystis utricularis and Monostroma hariotii) and sublittoral (Ascoseira mirabilis and Gigartina skottsbergii).

Results: Reproductive cells of eulittoral species showed the highest light demands $\left(E_{k}>45 \mu\right.$ mol photon $\mathrm{m}^{-2} \mathrm{~s}^{-1}$ ) when compared to those from sublittoral species $\left(E_{k}<30 \mu \mathrm{mol}\right.$ photon $\left.\mathrm{m}^{-2} \mathrm{~s}^{-1}\right)$. Short-term experiments of $1 \mathrm{~h}$ revealed that reproductive cells of $P$. endiviifolia, A. utricularis and $M$. hariotii had the highest temperature tolerance with a decrease of $F_{v} / F_{m}$ observed only at $30{ }^{\circ} \mathrm{C}$, while carpospores of $G$. skottsbergii exhibited the highest sensitivity to temperature increase with a decrease of $\mathrm{F}_{\mathrm{v}} / \mathrm{F}_{\mathrm{m}}$, which could be observed at $5^{\circ} \mathrm{C}$. UV tolerance was observed in reproductive cells of the eulittoral species with $<20 \%$ inhibition in $\mathrm{F}_{\mathrm{v}} / \mathrm{F}_{\mathrm{m}}$ from UV after four hours of exposure, while sublittoral species were more sensitive with $>30 \%$ inhibition in $\mathrm{F}_{\mathrm{v}} / \mathrm{F}_{\mathrm{m}}$ in the same condition. Enhanced temperature $\left(7\right.$ and $12{ }^{\circ} \mathrm{C}$ ) improved the tolerance of I. cordata compared to $2{ }^{\circ} \mathrm{C}$, but exacerbated the detrimental effects of UV on A. mirabilis.

Conclusion: Results showed that photosynthetic characteristics varied among reproductive cells of different species, reflecting the vertical zonation of parental thalli. Otherwise, these differences appear to underlie biogeographical and evolutionary components. In addition, UV tolerance was modulated by temperature increase, while temperature increase, in turn, ameliorated the detrimental effects of stress treatments in some eulittoral species (I. cordata tetraspores). In sublittoral A. mirabilis gametangia, temperature exacerbated the reduction of photosynthetic efficiency.
\end{abstract}

Keywords: Antarctica, Reproductive cells, Seaweeds, Temperature, UV tolerance

\section{Background}

The Antarctic environment is characterized by low temperatures and extremes in seasonal underwater light conditions. Macroalgae thrive by virtue of their highly efficient metabolic adaptations to photosynthesize and grow at low temperature and almost permanent low light conditions. However, during maturation and development of early phases, e.g., spores, gametes and embryonic thalli, Antarctic macroalgae can be vulnerable, especially to episodic

\footnotetext{
* Correspondence: nelso.navarro@umag.cl

${ }^{1}$ Instituto de Ciencias Marinas y Limnológicas, Universidad Austral de Chile, Casilla 567, Valdivia, Chile

${ }^{2}$ Universidad de Magallanes, Punta Arenas, Chile

Full list of author information is available at the end of the article
}

enhanced solar radiation during late winter-spring, following break-up of the ice cover (reviewed by [1]). Although studies have reported on the effects of UV radiation, temperature and their interactive effects on Antarctic macroalgae, they have mostly focused on the adult stages (e.g., $[2,3])$, while studies on early life stages are scarce. However, during the last decade, photosynthetic characteristics and UV effects on microscopic developmental stages, e.g., spores, gametes, propagules and plantlets, of some selected Antarctic macroalgae have been published [4-6] (see Table 1). These studies report that early life stages are also extremely shade-adapted and susceptible to environmental stresses, such as exposure to UV radiation [4, 7]. Even though the effect of UV on microscopic life history 
Table 1 Photosynthetic characteristics ( $E_{k}$ : $\left[\mu \mathrm{mol}\right.$ photon $\left.\mathrm{m}^{-2} \mathrm{~s}^{-1}\right]$, ETR $\max$ : $\left[\mu \mathrm{mol} \mathrm{e}^{-} \mathrm{m}^{-2} \mathrm{~s}^{-1}\right]$; $\mathrm{a}_{\mathrm{ETR}}\left[\mu \mathrm{mol} \mathrm{e}^{-} \mathrm{m}^{-2} \mathrm{~s}^{-1}\right]$. [ $\left[\mu \mathrm{mol} \text { photon } \mathrm{m}^{-2} \mathrm{~s}^{-1}\right]^{-1}$ ), inhibition by $\mathrm{UV}$ radiation compared to PAR, and subsequent recovery in the early developmental stages of Antarctic macroalgae

\begin{tabular}{|c|c|c|c|c|c|c|c|c|}
\hline Species/Stage & Depth & Ek & $\mathrm{ETR}_{\max }$ & $a_{E T R}$ & $F_{V} / F_{m}$ & UV inhibition & Recovery & Reference \\
\hline \multicolumn{9}{|l|}{ Ascoseira mirabilis } \\
\hline Gametangia & Deep sublittoral $(17-30 \mathrm{~m})$ & $17 \pm 5 c$ & $3.6 \pm 0.4$ & $0.21 \pm 0.03$ & $0.48 \pm 0.02$ & $30-60 \%(4 h)^{a}$ & $73-83 \%(4 h)$ & Present study \\
\hline Gametangia & Upper sublittoral & 52 & 5 & 0.09 & $0.40 \pm 0.06$ & $20-25 \%(1 h)^{b}$ & $100 \%(2 d)$ & {$[5]$} \\
\hline Conceptacles & Shallow sublittoral (1 m) & $52 \pm 14$ & $10.6 \pm 4.2$ & $0.20 \pm 0.04$ & $\sim 0.6$ & $0 \%(6 h)^{d}$ & $100 \%(14$ h) & [12] \\
\hline \multicolumn{9}{|l|}{ Adenocystis utricularis } \\
\hline Zoospores & Eulittoral & $59 \pm 6 c$ & $27 \pm 3$ & $0.45 \pm 0.01$ & $0.64 \pm 0.02$ & $5 \%(4 h)^{a}$ & $100 \%(4 \mathrm{~h})$ & Present study \\
\hline Zoospores & Eulittoral & 64 & 9 & 0.14 & $0.46 \pm 0.11$ & $37 \%(8 h)^{c}$ & $100 \%(48$ h) & [4] \\
\hline \multicolumn{9}{|l|}{ Cystosphaera jacquinotii } \\
\hline Receptacles & Deep sublittoral & $13 \pm 6$ & $3.8 \pm 1.7$ & $0.28 \pm 0.01$ & $\sim 7.2$ & $15-21 \%(2 h)^{e}$ & $\sim 90 \%$ (4 h) & [12] \\
\hline \multicolumn{9}{|l|}{ Gigartina skottsbergii } \\
\hline Carpospores & Sublittoral (5-8 m) & $27 \pm 9 c$ & $7 \pm 2$ & $0.27 \pm 0.05$ & $0.42 \pm 0.32$ & $30-60 \%(4 h)^{a}$ & $50-60 \%(4 \mathrm{~h})$ & Present study \\
\hline \multirow[t]{2}{*}{ Carpospores } & Sublittoral & $54 \pm 2$ & $6.87 \pm 0.18$ & 0.14 & $0.40 \pm 0.03$ & $1-3 \%(U V-B ; 8$ h) & $100 \%(2 d)$ & [6] \\
\hline & & & & & & $11-18 \%(\text { UV-A; } 8 \text { h) })^{b}$ & & \\
\hline \multirow[t]{2}{*}{ Tetraspores } & Sublittoral & $44 \pm 21$ & $5.60 \pm 0.08$ & 0.14 & $0.31 \pm 0.07$ & $4-7 \%$ (UV-B; 8 h) & $100 \%(2 d)$ & [6] \\
\hline & & & & & & $11-21 \%($ UV-A; 8 h) & & \\
\hline \multicolumn{9}{|l|}{ Iridaea cordata } \\
\hline Tetraspores & Eulittoral & $46 \pm 6 b c$ & $7.4 \pm 0.3$ & $0.17 \pm 0.03$ & $0.38 \pm 0.03$ & $20 \%(4 h)^{a}$ & $100 \%(4 h)$ & Present study \\
\hline \multirow[t]{2}{*}{ Tetraspores } & Upper sublittoral & 57 & 6.9 & 0.12 & $0.47 \pm 0.04$ & $\sim 25 \%(U V-B ; 8 h)^{b}$ & $100 \%(2 d)$ & [35] \\
\hline & & & & & & $\sim 30 \%($ UV-A; 8 h) & & \\
\hline \multicolumn{9}{|l|}{ Porphyra endiviifolia } \\
\hline Carpospores & Eulittoral & $101 \pm 19 b$ & $14 \pm 2$ & $0.14 \pm 0.01$ & $0.35 \pm 0.01$ & $20 \%(4 h)^{a}$ & $100 \%(4 h)$ & Present study \\
\hline Monospores & Upper eulittoral & 33 & 4 & 0.12 & $0.49 \pm 0.04$ & $0 \%(8 h)^{c}$ & $100 \%(48$ h) & [4] \\
\hline \multicolumn{9}{|l|}{ Monostroma hariotii } \\
\hline Gametes & Eulittoral & $295 \pm 84 a$ & $25 \pm 5$ & $0.09 \pm 0.01$ & $0.26 \pm 0.01$ & $20 \%(4 h)^{a}$ & $100 \%(4 h)$ & Present study \\
\hline Gametes & Eulittoral & 83 & 5 & 0.065 & $0.29 \pm 0.04$ & $0 \%(8 h)^{c}$ & $100 \%(48$ h) & [4] \\
\hline \multicolumn{9}{|l|}{ Urospora penicilliformis } \\
\hline \multirow[t]{2}{*}{ Zoospores, gametes } & Upper eulittoral & 87 & 14 & 0.16 & $\sim 0.50$ & $\sim 37 \%(U V-B ; 6 h)^{b}$ & $100 \%(24$ h) & [37] \\
\hline & & & & & & $\sim 33 \%($ UV-A; 6 h) & & \\
\hline \multirow[t]{2}{*}{ Gametophytes } & Upper eulittoral & 252 & 44 & 0.18 & $\sim 0.51$ & $\sim 26 \%(U V-B ; 6 h)^{b}$ & $94 \%(1$ h) & {$[37]$} \\
\hline & & & & & & $\sim 25 \%\left(\right.$ UV-A; 6 h) ${ }^{b}$ & & \\
\hline
\end{tabular}


stages has attracted more research attention, assessments of the combined impact of UV radiation and temperature are lacking. The importance of evaluating the impact of these factors on early stages lies in the fact that the life cycle and, in general, the whole fate of the macroalgal population depend on both reproductive output of parental thalli and the environmental tolerance of propagules [5, 7-11]. A recent study demonstrated that reproductive parental sporophytes show different UV sensitivity compared to vegetative individuals and, moreover, that algae invest considerable energy in synthesis and allocation of photoprotective substances [12]. In general, these are adaptive responses that can have important consequences for survival and establishment processes in scenarios of enhanced environmental variability driven by global climate change.

Temperature has become an environmental factor that could modify physiological responses of algae. In fact, temperature, both directly and indirectly, impacts seaweed biology from subcellular to community-level processes. In general, few studies have focused on thermal tolerance of photosynthesis in early phases of Antarctic macroalgae. However, some comparative studies at $0{ }^{\circ} \mathrm{C}$ indicate that microscopic gametophytes and embryonic sporophytes of the endemic brown alga Desmarestia menziesii show higher photosynthesis than adult sporophytes [13]. Overall, upper temperatures for development of early phases appear to be lower than those for macro thalli, showing a remarkable capacity to tolerate temperatures well above those measured in situ [1]. For example, some spores and gametophytes of Antarctic Desmarestiales grow in conditions reaching $15{ }^{\circ} \mathrm{C}$ with upper survival temperatures as high as $18{ }^{\circ} \mathrm{C}$ [14]. In adult thalli, enhanced temperature close to their thermal limit can exacerbate the detrimental UV effects of different physiological parameters [15-19]. However, it was demonstrated recently that increased temperature could also mitigate the damaging effects of UV radiation to photosystem II (PSII) in four Antarctic macroalgal species, thus improving their tolerance to UV [3]. Also, in the Artic kelp Saccharina latissima, which shows a physiological optimum at around $7{ }^{\circ} \mathrm{C}$, UV damage of the photosynthetic D1 protein was less severe at $12{ }^{\circ} \mathrm{C}$ than at $2{ }^{\circ} \mathrm{C}$, emphasizing the importance of temperature shifts on the photobiological responses of algae [20]. The question then arises whether enhanced temperature influences the photosynthetic responses of early phases, including spores and gametes, of Antarctic seaweeds and, if so, to what extent these developmental phases exhibit physiological mechanisms able to cope with both acute and chronic thermal stress.

To address these questions, the present study examines P-E-based photosynthetic characteristics and shortterm responses to different treatments of UV radiation and elevated temperature in reproductive cells, i.e., spores and gametes, of six species of macroalgae from the eulittoral and sublittoral of Fildes Peninsula (King George Island, Antarctica). We hypothesize that increased temperature will mitigate the detrimental effects of UV on photosynthesis in a manner similar to that reported in adult thalli. Since most Antarctic seaweeds show broad vertical distribution in a range between 5 and $30 \mathrm{~m}$, it could be expected that a) spores from populations of a species living at the upper limit of distribution will be more tolerant to temperature increase and UV radiation than their deeper counterparts, which should also show more shade-adapted characteristics, and b) enhanced temperature will improve the UV tolerance of early stages, especially in those algae with upper distribution.

\section{Methods}

Algal collection and processing

The brown algae Ascoseira mirabilis Skottsberg and Adenocystis utricularis (Bory) Skottsberg; the red algae Iridaea cordata (Turner) Bory, Gigartina skottsbergii Setchell \& Gardner and Pyropia endiviifolia (A \& E. Gepp H.G. Choi \& M.S. Hwang) (formerly Porphyra endivifolium) (Rhodophyta); and the green alga Monostroma hariotii Gain (Chlorophyta) were collected from Fildes Bay (King George Island, Antarctic) during January and February 2015. During this period, records from Onset HOBO Datalogger (Onset Computer Corporation, Bourne, MA) indicated that mean seawater temperature in Fildes Bay was $1.0 \pm 0.1^{\circ} \mathrm{C}$ in the subtidal zone $(15 \mathrm{~m})$, while surface water temperature averaged $2{ }^{\circ} \mathrm{C}$. During low tide, intertidal species were exposed to temperatures close to $10{ }^{\circ} \mathrm{C}$, especially during calm and sunny conditions. The zonation of Antarctic macroalgae and the most relevant photobiological scenarios at this locality have been previously described by [2]. After sampling, algae were transferred to the laboratory at the Chilean Antarctic Base Station Profesor Julio Escudero where they were cleaned of epiphytes and induced to release their spores and/or gametes.

\section{Release of spores and gametes}

Propagule release was induced by dehydration of reproductive fronds under a temperature of $2 \pm 0.5^{\circ} \mathrm{C}$. Spores and/or gametes were counted using a Neubauer counting chamber under a stereomicroscope (Motic Inc., Ltd.) before transfer to cell culture plate incubators (TrueLine, USA) with filtered $(0.2 \mu \mathrm{m})$ seawater. The spores were photographed under a light microscope (Motic BA310; Motic Inc., Ltd) in order to obtain cell diameters (Fig. 1). The density of cells in the suspension of each species was adjusted with filtered seawater to obtain $130 \mathrm{~mL}$ of stock suspension to obtain the desired background fluorescence for photosynthetic measurements. Thus, the reproductive cell density used in the experiments were as follows: $4.7 \mathrm{x}$ 
$10^{5}$ cells $\mathrm{mL}^{-1}$ of Adenocystis utricularis zoospores (mean diameter $6 \pm 1 \mu \mathrm{m}$ ), $6 \times 10^{4}$ cells $\mathrm{mL}^{-1}$ of Iridaea cordata tetraspores (mean diameter $18 \pm 2 \mu \mathrm{m}$ ), $2.25 \times 10^{4}$ cells $\mathrm{mL}^{-1}$ of Gigartina skottsbergii carpospores (mean diameter $25 \pm 2 \mu \mathrm{m}$ ), $1.09 \times 10^{5}$ cells $\mathrm{mL}^{-1}$ of Pyropia endiviifolia carpospores (mean diameter $12 \pm 1 \mu \mathrm{m}$ ), $1.36 \times 10^{6}$ cells $\mathrm{mL}^{-1}$ of Monostroma hariotii gametes (length around $5 \pm 0.5 \mu \mathrm{m})$, and $1.25 \times 10^{5}$ cells $\mathrm{mL}^{-1}$ of Ascoseira mirabilis gametangia (mean diameter $22 \pm 4 \mu \mathrm{m}$ ).

\section{Photosynthetic characteristics}

Immediately after spore release, photosynthesis was measured through relative electron transport rate (rETR)based P-E curves by exposing the cells to increasing (every $20 \mathrm{~s}$ ) actinic light intensities (8 points between $0-446 \mu \mathrm{mol}$

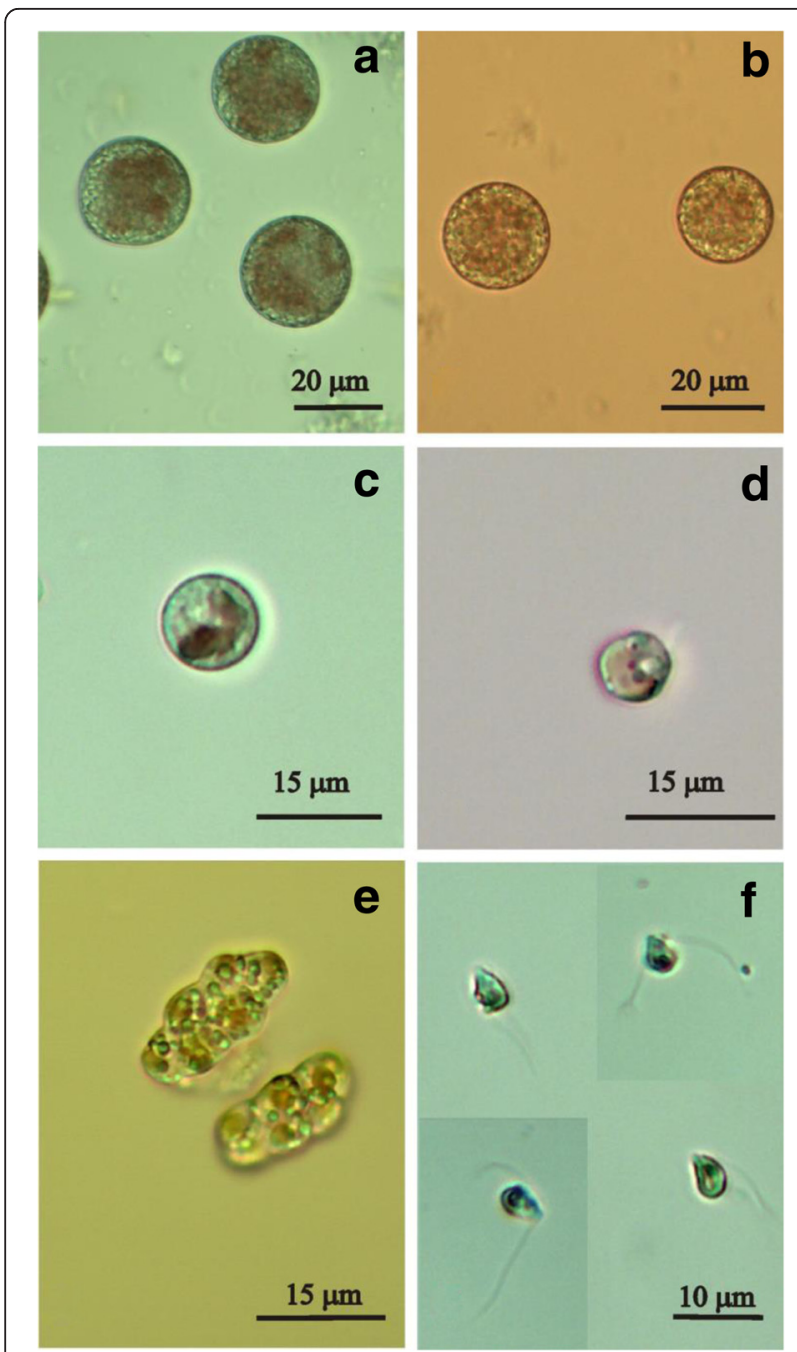

Fig 1 Reproductive cells of the six studied macroalgal species from Fildes Peninsula (King George Island, Antarctica). a: Gigartina skottsbergii carpospores; b: Iridaea cordata tetraspores; c: Pyropia endiviifolia carpospores; d: Adenocystis utricularis zoospores; e: Ascoseira mirabilis gametangia; $\mathbf{f}$ : Monostroma hariotii gametes photon $\mathrm{m}^{-2} \mathrm{~s}^{-1}$ ) with a Water-PAM fluorometer (Walz, Effeltrich, Germany). rETR values were estimated by multiplying the effective quantum yield of photosystem II $\left(\Phi_{\mathrm{PSII}}\right)$ with the corresponding intensity of the actinic irradiance [21], as

$$
\mathbf{r E T R}=\Phi_{\mathrm{PSII}} * \mathbf{E} * \mathbf{0 . 5},
$$

where $\mathrm{E}$ is the incident irradiance of actinic light. The factor 0.5 was derived assuming that 4 of the 8 electrons required to assimilate one $\mathrm{CO}_{2}$ molecule are supplied by PSII.

ETR parameters were obtained by fitting the ETRirradiance curve according to the modified nonlinear function of [22], as

$$
\mathbf{E T R}=\mathbf{r E T R}_{\max } * \tanh \left(\alpha * \mathbf{E} / \mathbf{r E T R}_{\max }\right),
$$

where $\mathrm{rETR}_{\max }$ is the maximal rETR, tanh is the hyperbolic tangent function, $\alpha$ is the efficiency of electron transport, i.e., initial slope of rETR versus irradiance curve, and $\mathrm{E}$ is the incident actinic irradiance. Finally, the saturating irradiance $\left(E_{k}\right)$ was calculated as the intersection between $\alpha$ and rETR $_{\text {max }}$.

\section{Exposure to increasing temperatures}

Aliquots $(4 \mathrm{~mL})$ from the suspension of reproductive cells were put inside cell culture plates $(n=5)$ and immediately submitted to a temperature gradient $(0,5,10$, $15,20,25$ and $30{ }^{\circ} \mathrm{C}$ ) using a heating unit (Digit-Cool, J.P. Selecta, Spain). After $1 \mathrm{~h}$ at $0{ }^{\circ} \mathrm{C}$, the effect of temperature on photosynthesis was assessed as rapid adjustment of photochemistry through changes in maximal quantum yield $\left(\mathrm{F}_{\mathrm{v}} / \mathrm{F}_{\mathrm{m}}\right)$ in algal samples previously kept in the darkness for $5 \mathrm{~min}$ at $0{ }^{\circ} \mathrm{C} . \mathrm{F}_{\mathrm{v}} / \mathrm{F}_{\mathrm{m}}$ is regarded as a reliable estimator of photosynthetic response to stress. After measuring, the samples were placed back into the heating system, and the temperature was increased at intervals of $5{ }^{\circ} \mathrm{C}$. Once the temperature rose to $5{ }^{\circ} \mathrm{C}$, the samples remained at that temperature for one hour, and $\mathrm{F}_{\mathrm{v}} / \mathrm{F}_{\mathrm{m}}$ was measured again. This procedure was carried out until reaching $30{ }^{\circ} \mathrm{C}$. During the experiments, samples were illuminated with $13 \mu \mathrm{mol} \mathrm{m} \mathrm{m}^{-2} \mathrm{~s}^{-1}$. Control measurements of $F_{v} / F_{m}$ were obtained at time zero.

\section{Exposure to UV radiation under different temperatures}

Cell culture plates containing spores or gametes were exposed to PAR + UV and PAR treatments for $4 \mathrm{~h}$ at temperatures of 2,7 and $12{ }^{\circ} \mathrm{C}$, followed by a 4-h recovery period under dim light $\left(<5 \mu \mathrm{mol}\right.$ photon $\left.\mathrm{m}^{-2} \mathrm{~s}^{-1}\right)$. The three temperature treatments were obtained using heating units. For illumination, a combination of UV (Q-Panel-313 and $340 \mathrm{~nm}$ fluorescent tubes; Q-Panel Co., Cleveland, $\mathrm{OH}$ ) and PAR lamps (Daylight, Philips; Amsterdam, the Netherlands) was used. The cell culture plates were 
covered with different cut-off filters in order to establish the two irradiation treatments: PAR only achieved by Ultraphan $395 \mathrm{~nm}$ (Digefra; Munich, Germany) and PAR + UV using Ultraphan $295 \mathrm{~nm}$. The levels of irradiation were measured with a RAMSES-ACC2-UV-VIS hyperspectral radiometer (Trios Optical Sensors; Oldenburg, Germany), and the spectra were weighted using the action spectrum for DNA damage [23] and photoinhibition of photosynthesis [24]. The experimental levels of UV-B radiation $\left(0.26 \mathrm{~W} \mathrm{~m}^{-2}\right)$ matched values measured in situ at Fildes Bay during the summer season [2]. However, UV-A levels $\left(1.5 \mathrm{~W} \mathrm{~m}^{-2}\right)$ and UV-A:UV-B ratios were lower than those occurring under natural conditions. The weighted values were 0.08 (DNA damage) and $0.19 \mathrm{Wm}^{-2}$ (photoinhibition of photosynthesis). The irradiance of PAR $\left(13 \mu \mathrm{mol} \mathrm{m} \mathrm{m}^{-2} \mathrm{~s}^{-1}\right)$ remained low to avoid masking UV effects [2].

Four $\mathrm{mL}$ of each cell suspension were used per replicate $(n=4)$ for each temperature and light treatment. Initial measurements of $\mathrm{F}_{\mathrm{v}} / \mathrm{F}_{\mathrm{m}}$ were obtained at time zero. The effect of UV radiation under different temperatures was assessed as inhibition of $F_{v} / F_{m}$. Values were determined as a percentage of decrease between samples treated with PAR + UV and samples exposed to PAR. Similarly, the recovery was estimated by comparing the $\mathrm{F}_{\mathrm{v}} / \mathrm{F}_{\mathrm{m}}$ values of samples exposed to $\mathrm{UV}$ treatment with those from PAR treatment.

\section{Statistical analysis}

Photosynthetic light requirement $\left(\mathrm{E}_{\mathrm{k}}\right)$ values of each species were compared using one-way ANOVA. The effect of temperature on $\mathrm{F}_{\mathrm{v}} / \mathrm{F}_{\mathrm{m}}$ for each species was compared using repeated measures ANOVA (RMANOVA). In the case of the effect of $\mathrm{UV}$ on $\mathrm{F}_{\mathrm{v}} / \mathrm{F}_{\mathrm{m}}$ inhibition under different temperatures, two-way ANOVA was performed. Post-hoc comparisons of means were assessed with Tukey HSD. All analyses were done using the Statistica 7 software (StatSoft, Inc., USA).

\section{Results}

\section{Photosynthetic characteristics}

Photosynthetic performance of reproductive cells is shown in Fig. 2, while photosynthetic characteristics $\left(E T R_{\max }, \alpha\right.$ and $\left.\mathrm{E}_{\mathrm{k}}\right)$ are shown in Table 1 . The reproductive cells of the different species showed marked differences in saturating irradiance of photosynthesis (ANOVA: $\mathrm{F}=26.75 ; p<0.00001$ ) (Table 1, Fig. 2). Reproductive cells of the eulittoral species A. utricularis, $M$. hariotii and $P$. endiviifolia showed the highest light demands $\left(E_{k}>60 \mu\right.$ mol photon $\left.\mathrm{m}^{-2} \mathrm{~s}^{-1}\right)$ and $\mathrm{rETR}_{\max }$ (>14 $\mu \mathrm{mol} \mathrm{e}^{-} \mathrm{m}^{-2} \mathrm{~s}^{-1}$ ), while the sublittoral species $G$. skottsbergii and $A$. mirabilis showed the lowest light demands $\left(\mathrm{E}_{\mathrm{k}}<27 \mu \mathrm{mol}\right.$ photon $\left.\mathrm{m}^{-2} \mathrm{~s}^{-1}\right)$ and $\mathrm{ETR}_{\max }$ $\left(<7 \mu \mathrm{mol} \mathrm{e} \mathrm{e}^{-} \mathrm{m}^{-2} \mathrm{~s}^{-1}\right)$. Tetraspores of the eulittoral red

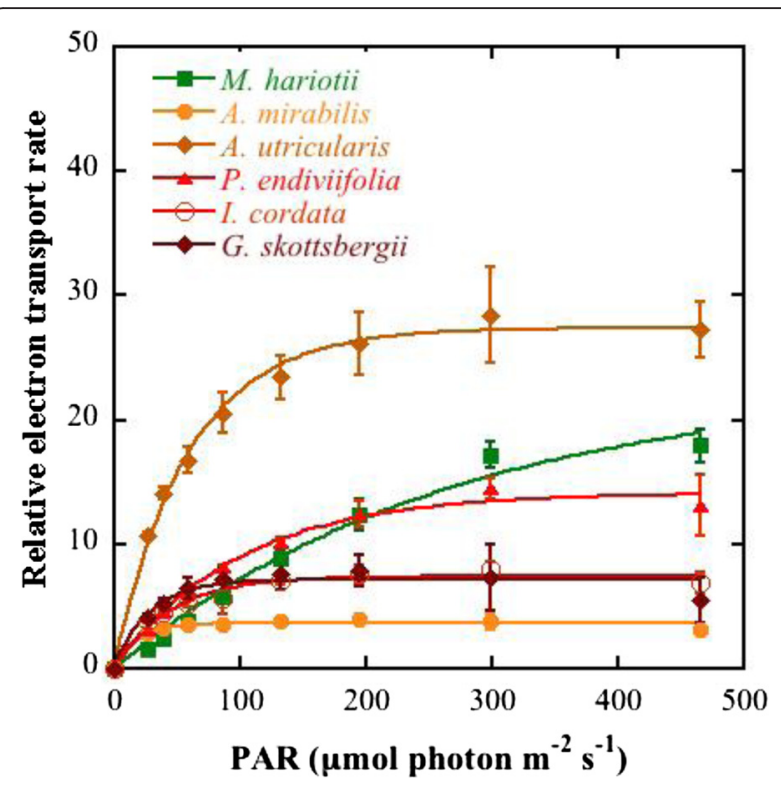

Fig 2 Electron transport rate (rETR) based on P-E curves of reproductive cells of Adenocystis utricularis, Monostroma hariotii, Pyropia endiviifolia, Iridaea cordata, Gigartina skottsbergii, and Ascoseira mirabilis collected in Fildes Peninsula (King George Island, Antarctica). Values are means \pm S.D. of 4 measurements

alga $I$. cordata exhibited $\mathrm{E}_{\mathrm{k}}$ values significantly different when compared to the other eulittoral species and when compared to sublittoral species (Table 1, Fig. 2).

\section{Temperature tolerance}

In the six studied species, increases in temperature caused a substantial decrease in $\mathrm{F}_{\mathrm{v}} / \mathrm{F}_{\mathrm{m}}$ (Fig. 3). In $P$. endiviifolia, $A$. utricularis and $M$. hariotii, the decrease in $\mathrm{F}_{\mathrm{v}} / \mathrm{F}_{\mathrm{m}}$ was observed only at $30{ }^{\circ} \mathrm{C}$, while in A. mirabilis, I. cordata and G. skottsbergii, it was observed at 25,20 and $5{ }^{\circ} \mathrm{C}$, respectively. On the other hand, only gametes of $M$. hariotii showed a significant increasing trend in their $\mathrm{F}_{\mathrm{v}} / \mathrm{F}_{\mathrm{m}}$ values between 0 to $25^{\circ} \mathrm{C}$ (Fig. 3).

\section{Tolerance to UV radiation and temperature}

UV exposure caused decreases in $F_{v} / F_{m}$ of reproductive cells in all studied species (Fig. 4). UV tolerance varied among species. Zoospores of $A$. utricularis were the most tolerant, while G. skottsbergii carpospores were the most sensitive. Species from eulittoral showed decreases less than, or equal to, $20 \%$, while in the sublittoral red alga $G$. skottsbergii, decreases under UV treatment ranged between 30 and $65 \%$.

UV tolerance was affected by temperature in $A$. utricularis $(\mathrm{F}=4.9 ; p<0.04)$, I. cordata $(\mathrm{F}=11.3 ; p<0.005)$ and A. mirabilis $(\mathrm{F}=19.1 ; p<0.005)$. In I. cordata, tolerance increased with temperature, while in A. mirabilis, gametes were more sensitive to UV radiation under $12{ }^{\circ} \mathrm{C}$. In $A$. utricularis, exposure to $7{ }^{\circ} \mathrm{C}$ increased $\mathrm{F}_{\mathrm{v}} / \mathrm{F}_{\mathrm{m}}$. 


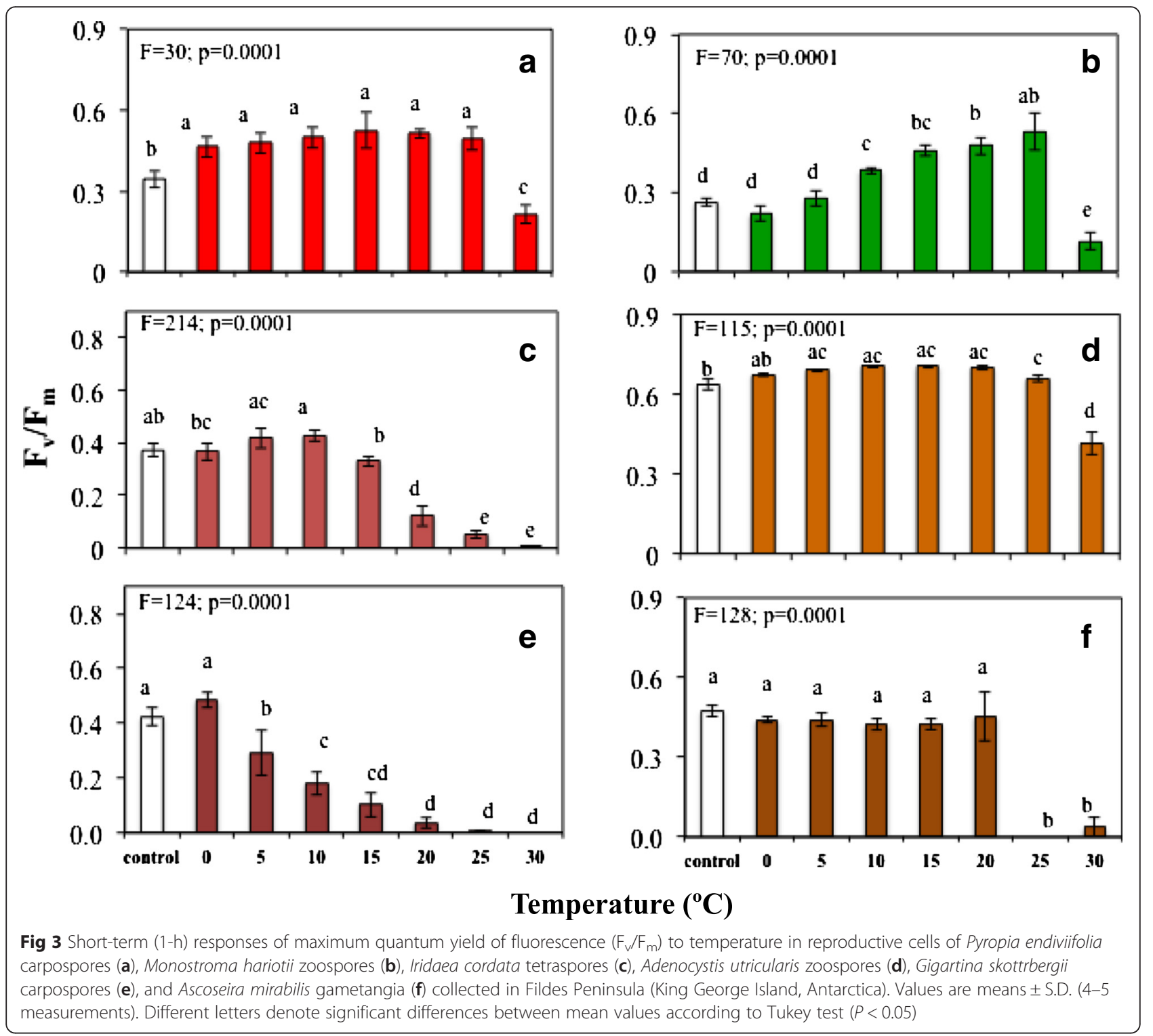

After $4 \mathrm{~h}$ under dim light, the eulittoral species recovered almost completely (95-100 \%) in all temperature treatments. In sublittoral species, the recovery reached values between 50 and $80 \%$, with the exception of $G$. skottsbergii whose carpospores recovered completely at $12{ }^{\circ} \mathrm{C}$.

\section{Discussion}

\section{Photosynthetic characteristics}

Differences in photosynthetic performance among reproductive cells, such as spores and/or gametes, of the studied species were observed. These differences could be related to the type of reproductive cell, which can have different features, such as size, motility or pigment composition. Notwithstanding such species-specific differences, photosynthetic characteristics of reproductive cells allowed us to distinguish between eulittoral and sublittoral algae, the former having higher irradiance saturation. These results are in agreement with the actual position of these species on the shore, and they confirm previous reports of [4].

Among eulittoral species, reproductive cells of $I$. cordata and A. utricularis seem to be strongly adapted to low light, while $M$. hariotii and $P$. endiviifolia are less shade-adapted, even though $M$. hariotii is distributed in the lower eulittoral [2]. In contrast, [4] reported that spores of $P$. endiviifolia are strongly shade-adapted and that propagules of $A$. utricularis and $M$. hariotii seem to be less shade-adapted (for comparison, see Table 1). Differences between these studies could result from the number of spores used in the measurements, time of release of spores or reproductive season. In this context, 


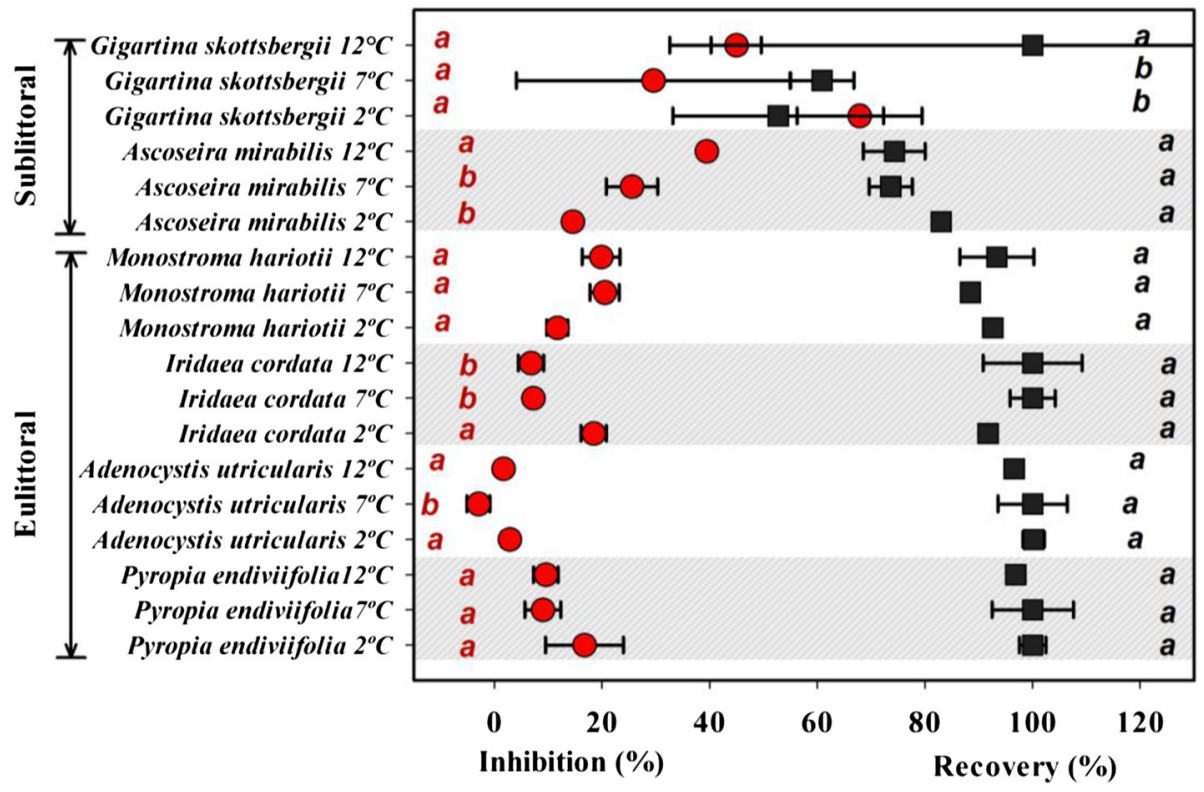

Fig 4 Inhibition of maximum quantum yield of fluorescence $\left(F_{v} / F_{m}\right)$ after a 4-h exposure to UV radiation and subsequent 4-h recovery in reproductive cells of Adenocystis utricularis, Monostroma hariotii, Pyropia endiviifolia, Iridaea cordata, Gigartina skottsbergii, and Ascoseira mirabilis collected in Fildes Peninsula (King George Island, Antarctica). Values are mean \pm S.D. (4-5 measurements) and represent the percentage reduction in $F_{v} / F_{m}$ of UV treatment relative to PAR exposure. Different letters denote significant differences between mean values within temperature treatments according to Tukey test $(P<0.05)$

the photosynthetic capacity of sporelings in suspension could partially reflect the depth distribution of the parental thalli because macroalgal zonation is ultimately defined by the ability of algae to tolerate environmental stress through adaptations of more advanced developmental processes, such as germination, settlement and growth [9-10].

\section{Temperature tolerance}

In our study, adaptation of the studied species to cold was confirmed by the high photosynthetic efficiency under $0^{\circ}$ C. However, a remarkable photosynthetic capacity was also observed at high temperatures, mainly in the eulittoral species $A$. utricularis, $M$. hariotii and $P$. endiviifolia, a phenomenon previously been observed in propagules, gametophytes and embryonic sporophytes of several Antarctic and Arctic species of macroalgae (reviewed in [1]. These results suggest that reproductive cells of these three species are thermally well adapted, at least for short periods of time, allowing them to develop in a highly variable environment. This ability apparently forms part of a suite of adaptive mechanisms displayed by these species, enabling their spread and colonization of different biogeographic regions. In fact, $A$. utricularis and $M$. hariotii are widely distributed in subantarctic and temperate coasts of South America [25]. In contrast, carpospores of G. skottsbergii exhibited a high sensitivity to enhanced temperature, which agrees with the ranges for growth reported for this species $\left(0\right.$ and $5^{\circ} \mathrm{C} ;[26,27]$. Interestingly, gametes of $A$. mirabilis, an endemic Antarctic species, showed high temperature tolerance. This can be partially explained by the upper vertical distribution of the parental sporophytes. It should be noted that $A$. mirabilis can colonize the infralittoral fringe during spring-summer. Alternatively, tolerance to high temperatures could be a conserved trait related to the fact that the species is probably a relict of Mesozoic (Gondwana) marine flora, which was highly diverse when the average water temperatures were close to $12{ }^{\circ} \mathrm{C}$ [28].

\section{Temperature and UV tolerance}

Our results indicated an interactive effect of UV and temperature on $\mathrm{F}_{\mathrm{v}} / \mathrm{F}_{\mathrm{m}}$ of reproductive cells of some Antarctic algae. For example, a decline in photochemical yield by UV radiation was found in G. skottsbergii carpospores, and such decrease was exacerbated under exposure to $2{ }^{\circ} \mathrm{C}$. In contrast, inhibition of photosynthesis decreased at temperatures of $12{ }^{\circ} \mathrm{C}$. A similar tendency, although less marked, was observed in $I$. cordata and $P$. endiviifolia. It is known that various processes related to photoprotection, e.g., D1 protein turnover, enzyme repair mechanisms, and dissipative quenching, operate more efficiently at higher temperatures $[29,30]$. Thus, the lower inhibition of photosynthesis observed at $12{ }^{\circ} \mathrm{C}$ compared to 2 and $7{ }^{\circ} \mathrm{C}$ could be regarded as an efficient acclimation of photosynthesis in these macroalgae. For 
example, the UV-mediated inhibition of photosynthesis at $10{ }^{\circ} \mathrm{C}$ of the Antarctic Ulva bulbosa was close to $10 \%$, comparable to its subantarctic counterpart Ulva clathrata. However, at $0{ }^{\circ} \mathrm{C}$, decreases in photosynthesis reach a peak at 37 and $50 \%$ relative to control, respectively [31]. Compared to enzymatic processes, photochemical reactions, such as $\mathrm{CO}_{2}$ fixation or ATPase reactions [32], are relatively unaffected by temperature, while, on the other hand, chlorophyll turnover and PSIIrelated reactions are highly sensitive to low temperature, thus exacerbating inhibition and photochemical damage [33]. This apparently explains why photodamage of PSII under high solar radiation is enhanced at low temperatures [34].

Decreases in $\mathrm{F}_{\mathrm{v}} / \mathrm{F}_{\mathrm{m}}$, as measured in $A$. mirabilis gametangia at $2{ }^{\circ} \mathrm{C}$, were comparable to those observed in $P$. endiviifolia and I. cordata. It must be emphasized that differences in UV tolerance between propagules of different species are a reflection of both the capacity for stress tolerance, as well as other morphofunctional aspects related to cell size, pigmentation, previous UV exposure history within gametangia/sporangia [12], and even the levels and time of UV exposure used in experiments (see Table 1). In the case of size, UV susceptibility has been shown to decrease with increasing cell size in terms of $\mathrm{F}_{\mathrm{v}} / \mathrm{F}_{\mathrm{m}}[6]$ and DNA damage $[4,6]$. In larger propagules observed in our study, such as carpospores of Iridaea $(18 \pm 2 \mu \mathrm{m})$ and Pyropia $(12 \pm 1 \mu \mathrm{m})$ and gamentangia of Ascoseira $(22 \pm 4 \mu \mathrm{m})$, direct UV effect was lower, most likely resulting from the longer pathway for UV penetration [8]. Furthermore, the highest UV tolerance of some reproductive cells has been associated with the presence of UV-absorbing compounds $[6,35,36]$. On the other hand, cell walls of gametangia and auxiliary structures in conceptacles of A. mirabilis could offer UV protection to the gametes inside $[5,12]$.

In the context of global climate change, the ability of early developmental stages to withstand environmental variability is essential for recruitment, especially for those species subject to episodic perturbations from, for example, ice scouring, as their recovery over time depends almost entirely on reproductive output and capacity for rapid settlement.

To the best of our knowledge, only a few studies have addressed the response of spores of Antarctic macroalgae to UV radiation, while no data have thus far been published on the response to different temperatures or the interaction between UV exposure and temperature. Thus, our study is among the first to provide evidence that reproductive cells of Antarctic macroalgae are relatively tolerant to high temperature and that temperature increase can modulate UV tolerance, at least under laboratory conditions.

\section{Conclusions}

- Photosynthetic characteristics among reproductive cells of the six studied species varied according to the bathymetric distribution of parental adult stages. As such, eulittoral species exhibited higher light requirements for photosynthesis than sublittoral algae. However, other factors related to biogeographic distribution or evolutionary divergences could affect the patterns determined in this study.

- Reproductive cells of eulittoral species exhibited higher temperature tolerance than sublittoral algae, at least in the short term.

- UV tolerance was ameliorated by enhanced temperature in three of the six studied species. Moreover, reproductive cells of the six studied species could recover within $4 \mathrm{~h}$ after UV exposure in a manner unrelated to temperature.

- Although these results indicating acclimation to short-term exposure point to an ecological advantage of eulittoral over sublittoral species, further research based on long-term incubation will provide new insights into the potential mechanisms that permit these algae to cope with large-scale environmental variability.

Competing interests

The authors declare that they have no competing interests.

Authors' contributions

NPN: Laboratory or fieldwork, Data analysis and interpretation, Manuscript preparation. PH: Framing hypotheses/experi-mental design, Data analysis and interpretation, Manuscript preparation. IG: Framing hypotheses/experi-mental design, Data analysis and interpretation, Manuscript preparation. All authors read and approved the final manuscript.

\section{Acknowledgments}

The authors are grateful to the Comisión Nacional de Investigación Científica y Tecnológica (CONICYT) for financial support through the grant ANILLO ART1101. The authors thank the Instituto Antártico Chileno (INACH) for logistical support at the Antarctic Base Station Profesor Julio Escudero. We also thank the scientific diving team of I. Garrido, M. J. Díaz, and J. Bravo for collecting the macroalgal material. This is contribution \# 10 of the ANILLO ART1101 project.

\section{Author details}

${ }^{1}$ Instituto de Ciencias Marinas y Limnológicas, Universidad Austral de Chile, Casilla 567, Valdivia, Chile. 'Universidad de Magallanes, Punta Arenas, Chile. ${ }^{3}$ Centro FONDAP de Investigaciones de Ecosistemas Marinos de Altas Latitudes (IDEAL), Valdivia, Chile.

Received: 17 November 2015 Accepted: 9 February 2016 Published online: 04 April 2016

\section{References}

1. Gómez I, Wulff A, Roleda MY, Huovinen P, Karsten U, Quartino ML, et al. Light and temperature demands of marine benthic microalgae and seaweeds in polar regions. Bot Mar. 2009;52:593-608.

2. Huovinen P, Gómez I. Photosynthetic characteristics and UV stress tolerance of Antarctic seaweeds along the depth gradient. Polar Biol. 2013;36:1319-32.

3. Rautenberger R, Huovinen P, Gómez I. Effects of increased seawater temperature on UV tolerance of Antarctic marine macroalgae. Mar Biol. 2015;162:1087-97. 
4. Zacher K, Roleda MY, Hanelt D, Wiencke C. UV effects on photosynthesis and DNA in propagules of three Antarctic seaweeds (Adenocystis utricularis, Monostroma hariotii and Porphyra endiviifolium). Planta. 2007;225:1505-16.

5. Roleda MY, Zacher K, Wulff A, Hanelt D, Wiencke C. Photosynthetic performance, DNA damage and repair in gametes of the endemic Antarctic brown alga Ascoseira mirabilis exposed to ultraviolet radiation. Austral Ecol. 2007a;32:917-26.

6. Roleda MY, Zacher K, Wulff A, Hanelt D, Wiencke C. Susceptibility of spores of different ploidy levels from Antarctic Gigartina skottsbergii (Gigartinales, Rhodophyta) to ultraviolet radiation. Phycologia. 2008;47:361-70.

7. Roleda MY, Wiencke C, Hanelt D, Bischof K. Sensitivity of the early life stages of macroalgae from the northern hemisphere to ultraviolet radiation. Photochem Photobiol. 2007b;83:1-12.

8. Swanson AK, Druehl LD. Differential meiospore size and tolerance of ultraviolet light stress within and among kelp species along a depth gradient. Mar Biol. 2000;136:657-64.

9. Wiencke C, Clayton MN. Antarctic Seaweeds. KG Ruggell, Liechtenstein: ARG Gantner Verlag; 2002. p. 1-239.

10. Wiencke C, Roleda MY, Gruber A, Clayton MN, Bischof K. Susceptibility of zoospores to UV radiation determines upper depth distribution limit of Arctic kelps: evidence through field experiments. J Ecol. 2006;94:455-63.

11. Véliz K, Edding M, Tala F, Gómez I. Effects of ultraviolet radiation on different life cycle stages of the south Pacific kelps, Lessonia nigrescens and Lessonia trabeculata (Laminariales, Phaeophyceae). Mar Biol. 2006;149:1015-24.

12. Huovinen P, Gómez I. UV Sensitivity of vegetative and reproductive tissues of three Antarctic macroalgae is related to differential allocation of phenolic substances. Photochem Photobiol. 2015;91:1382-8.

13. Gómez I, Wiencke C. Photosynthesis, dark respiration and pigment contents of gametophytes and sporophytes of the Antarctic brown alga Desmarestia menziesii. Bot Mar. 1996;39:149-57.

14. Wiencke C, Tom Dieck I. Temperature requirements for growth and temperature tolerance of macroalgae endemic to the Antarctic region. Mar Ecol Progr Ser. 1989;54:189-97.

15. Gómez I, Figueroa FL, Sousa-Pinto I, Viñegla B, Pérez-Rodríguez E, Maestre C, et al. Effects of UV radiation and temperature on photosynthesis as measured by PAM fluorescence in the red alga Gelidium pulchellum (Turner) Kützing. Bot Mar. 2001;44:9-16.

16. Fredersdorf J, Müller R, Becker S, Wiencke C, Bischof K. Interactive effects of radiation, temperature and salinity on different life history stages of Arctic kelp Alaria esculenta (Phaeophyceae). Oecologia. 2009;160:483-92.

17. Steinhoff FS, Wiencke $Z C$, Wuttke S, Bischof K. Effects of water temperatures, UV radiation and low vs high PAR on phlorotannin content and germination in zoospores of Saccorhiza dermatodea (Tilopteridales, Phaeophyceae). Phycologia. 2011;50:256-63.

18. Heinrich S, Valentin K, Frickenhaus S, John U, Wiencke C. Transcriptomic analysis of acclimation to temperature and light stress in Saccharina latissima (Phaeophyceae). PLoS One. 2012;7(8):e44342. doi:10.1371/journal. pone.0044342.

19. Cruces E, Huovinen P, Gómez I. Interactive effects of UV radiation and enhanced temperature on photosynthesis, phlorotannin induction and antioxidant activities of two sub-Antarctic Brown algae. Mar Biol. 2013;160:1-13.

20. Heinrich S, Valentin K, Frickenhaus S, Wiencke C. Temperature and light interactively modulate gene expression in Saccharina latissima (Phaeophyceae). J Phycol. 2015:51:93-108.

21. Schreiber U, Bilger W, Neubauer C. Chlorophyll fluorescence as a non-intrusive indicator for rapid assessment of in vivo photosynthesis. Ecol Stud. 1994;100:49-70.

22. Jassby AD, Platt T. Mathematical formulation of the relationship between photosynthesis and light for phytoplankton. Limnol Oceonogr. 1976;21:540-7.

23. Setlow RB. The wavelengths in sunlight effective in producing skin cancer: a theoretical analysis. Proc Nat Acad Sci USA. 1974;71:3363-6.

24. Jones LW, Kok B. Photoinhibition of chloroplast reactions. I. Kinetics and action spectra. Plant Physiol. 1966:41:1037-43.

25. Huovinen P, Gómez I. Cold Temperate seaweed communities of the southern hemisphere. In: Wiencke C, Bischof K, editors. Seaweed biology. Novel insights into ecophysiology, ecology and utilization, Ecological Studies, vol. 219. Berlin Heidelberg: Springer; 2012. p. 293-313.

26. Bischoff-Bäsmann B, Wiencke C. Temperature requeriments for growth and survival of Antarctic Rhodophyta. J Phycol. 1996;32:525-35.

27. Eggert A, Wiencke C. Adaptation and acclimation of growth and photosynthesis of five Antarctic red algae to low temperatures. Polar Biol. 2000;23:609-18.
28. Clayton MN. The evolution of the Antarctic marine benthic algal flora. J Phycol. 1994;30:897-904.

29. Wünschmann G, Brand JJ. Rapid turnover of a component required for photosynthesis explains temperatura dependence and kinetics of photoinhibition in a cyanobacterium, Synechococcus 6301. Planta. 1992;186:426-33.

30. Becker $\mathrm{S}$, Graeve M, Bischof K. Photosynthesis and lipid composition in the Antarctic rhodophyte Palmaria decipiens: effects of changing light and temperature levels. Polar Biol. 2010;33:945-55.

31. Rautenberger R, Bischof K. Impact of temperature on UVsusceptibility of two Ulva (Chlorophyta) species from Antarctic and Subantarctic regions. Polar Biol. 2006:29:988-96.

32. Osmond CB. What is photoinhibition? Some insights from comparisons shade and sun plants. In: Baker NR, Bowyer JT, editors. Photoinhibition of Photosynthesis: from Molecular Mechanism to the Field. Oxford: BIOS Scientific Pub; 1994. p. 1224

33. Nishiyama Y, Yamamoto H, Allakhverdiev SI, Inaba M, Yokota A, Murata N. Oxidative stress inhibits the repair of photodamage to the photosynthetic machinery. EMBO J. 2001;20:5587-94.

34. Öquist $G$, Hurry VM, Huner PA. The temperature dependence of the redox state of $Q_{A}$ and susceptibility of photosynthesis to photoinhibition. J Plant Physiol Biochem. 1993;31:683-9.

35. Zacher K, Roleda MY, Wulff A, Hanelt D, Wiencke C. Responses of Antarctic Iridaea cordata (Rhodophyta) tetraspores exposed to ultraviolet radiation. Phycol Res. 2009;57:186-93.

36. Wiencke C, Clayton M, Schoenwaelder M. Sensitivity and acclimation to UV radiation of zoospores from five species of Laminariales from the Arctic. Mar Biol. 2004;145:31-9.

37. Roleda MY, Campana G, Wiencke C, Hanelt D, Quartino ML, Wulff A. Sensitivity of Antarctic Urospora penicilliformis (Ulotrichales, Chlorophyta) to ultraviolet radiation is life stage dependent. J Phycol. 2009;45:600-9.

\section{Submit your next manuscript to BioMed Central and we will help you at every step:}

- We accept pre-submission inquiries

- Our selector tool helps you to find the most relevant journal

- We provide round the clock customer support

- Convenient online submission

- Thorough peer review

- Inclusion in PubMed and all major indexing services

- Maximum visibility for your research

Submit your manuscript at www.biomedcentral.com/submit
C) Biomed Central 